\title{
Spatial and temporal distribution of planktonic protists in the East Greenland fjord and offshore waters
}

\author{
D. W. Krawczyk ${ }^{1, *}$, K. E. Arendt ${ }^{1}$, T. Juul-Pedersen ${ }^{1}$, M. K. Sejr ${ }^{2}$, M. E. Blicher ${ }^{1}$, \\ H. H. Jakobsen ${ }^{3}$ \\ ${ }^{1}$ Greenland Climate Research Centre, Greenland Institute of Natural Resources, Box 570, 3900 Nuuk, Greenland \\ ${ }^{2}$ Arctic Research Centre, Aarhus University, 8000 Aarhus C, Denmark \\ ${ }^{3}$ Bioscience, Aarhus University, 4000 Roskilde, Denmark
}

\begin{abstract}
Summer planktonic protist assemblages $(>20 \mu \mathrm{m})$ were investigated in the East Greenland Young Sound fjord and offshore waters between 2009 and 2012. Samples were taken using $20 \mu \mathrm{m}$ mesh nets and Niskin bottles, fixed in acidic Lugol's solution, and analysed by microscopy. Comparison between the 2 methods showed that important colonial species present in net haul samples were not present in the water bottle samples. In Young Sound waters, the planktonic protist taxa varied significantly, corresponding to temperature and salinity gradients driven by runoff from the Greenland Ice Sheet. Fjord waters were characterised by diatoms and colonial chrysophyte species associated with meltwater (sea ice) and freshwater (snow and ice) input. Time series data from Young Sound showed inter-annual variations among the planktonic protist taxa due to dynamic water exchange between the inner and outer fjord. Little spatial variation among taxa was observed in offshore waters, which were characterized by diatoms, silicoflagellates, and dinoflagellates. Different diatom compositions were observed in the shelf area dominated by the cold East Greenland Current and in the warmer Atlantic waters of the Mid Denmark Strait. Silicoflagellates characterised sub-surface water masses of the Greenland Sea, which were influenced by saline oceanic waters, possibly Modified Atlantic Water. Our study shows that summer planktonic protist assemblages varied along the East Greenland coast due to freshwater inputs, sea ice melt, and Polar and Atlantic water circulation.
\end{abstract}

KEY WORDS: Arctic species richness - East Greenland · Arctic fjord $\cdot$ Sea ice melt $\cdot$ Atlantic waters · Time series

\section{INTRODUCTION}

The physical environment of the Arctic is changing more rapidly than the global average (e.g. Graversen et al. 2008). Increasing air temperatures, declining sea ice maximal extent and thickness (Comiso et al. 2008), and increasing freshwater runoff from the Greenland Ice Sheet (Hanna et al. 2008, Vinther et al. 2009) have been observed over the past decades. In recent years, there has been an increased input of

\footnotetext{
${ }^{*}$ Corresponding author: dikr@natur.gl
}

sea ice meltwater from the Arctic Ocean to the East Greenland Current (EGC) (Dodd et al. 2012) as well as changes in the intermediate and deep waters between the Arctic Ocean and the Nordic Seas (Langehaug \& Falck 2012). Changes in sea ice conditions and freshwater discharge in particular are expected to have implications for the marine ecosystem (Hamilton et al. 2013).

Along the East Greenland coast, melting sea ice and glacial discharge influence the structure, succes-

() The authors 2015. Open Access under Creative Commons by Attribution Licence. Use, distribution and reproduction are unrestricted. Authors and original publication must be credited. 
sion, and distribution of marine phytoplankton and other protists inhabiting adjacent waters (e.g. Gradinger \& Baumann 1991, Quillfeldt 1996, 2001). Diatom blooms in particular tend to follow the receding ice edge in the Fram Strait during summer, with changing species composition over the growing season (Gradinger \& Baumann 1991). Spring and summer phytoplankton bloom assemblages vary depending on seasonal sea ice cover in NE Greenland waters (e.g. Quillfeldt 1997, 2001). The distribution of various planktonic protists in the East Greenland region is also driven by water mass exchange and the North Atlantic Ocean current system (Hasle \& Syvertsen 1996), encompassing Polar and Atlantic waters. There is, however, only limited knowledge of the relationships between planktonic protists and the physical variables (such as temperature, salinity, and water masses) that influence their structure, succession, and distribution.

There is a growing need to monitor the Arctic and North Atlantic ecosystems over time scales that mirror the scale at which variability in physical environment occurs (Leong et al. 2005, Degerlund \& Eilertsen 2010). Satellite remote sensing of ocean transparency (e.g. Siegel \& Franz 2010) is often used to examine biomass and primary production. However, such estimates are limited to measurements of state variables that are not transferrable to rate measurements. Satellite data are also limited to the ocean surface, and as such are unable to measure sub-surface processes, species dynamics, and the dynamics of light absorption for biomass conversion. Furthermore, satellite data is only valid during ice-free and cloud-free conditions (Hamilton et al. 2013). The lack of baseline information in Arctic marine biology is likely preventing the identification of more subtle but widespread climate-related changes. In addition, more information and knowledge are needed concerning the physical factors driving natural variation. Ongoing long-term studies of ecosystem changes in SW and NE Greenland (i.e. the Greenland Ecosystem Monitoring programme, GEM) have shown annual and seasonal successions in marine plankton groups driven by various environmental factors, including freshwater runoff from the Greenland Ice Sheet (Juul-Pedersen et al. 2012, Sejr et al. 2012, Krawczyk et al. 2014) and inflow of the oceanic current (JuulPedersen et al. 2010).

Unicellular plankton can span a wide size continuum, from sub-micron sized photosynthetic bacteria to $>1000 \mu \mathrm{m}$ particles (Sheldon \& Parsons 1967, Sosik et al. 1989). Particles $>20 \mu \mathrm{m}$ are important in the concept of the classic food web (e.g. Fenchel 1988), as they serve as a link between primary and secondary production, which ultimately feeds larger organisms such as fish, marine mammals, and sea birds. We focused our study on summer planktonic protists $>20 \mu \mathrm{m}$ in order to understand the group of organisms that ultimately links to secondary production. We placed particular emphasis on physical drivers such as ocean currents, melting sea ice, and temperature. Data were collected from the East Greenland region using 2 sampling methods (net hauls and water bottles); each method was evaluated for individual advantages and weaknesses.

The present study describes the distribution of planktonic protist assemblages in relation to measured variables and regional hydrographic conditions within the study area. We quantified these changes on different scales, ranging from small-scale variations in sampled water depths to large-scale variations in regional domains throughout the East Greenland region. We also hypothesised that, compared to offshore waters, fjord waters would display much greater spatial variation in species richness due to their higher and more dynamic input of meltwater and freshwater. Our paper provides baseline data on East Greenland summer planktonic protists, their richness, and their variation in space and time.

\section{MATERIALS AND METHODS}

\section{Study site}

The study site covers the East Greenland region, i.e. Young Sound fjord and the offshore waters of the Greenland Sea, East Greenland Shelf, and the Mid Denmark Strait between $66^{\circ} 55^{\prime}$ and $74^{\circ} 35^{\prime} \mathrm{N}$, and $13^{\circ} 03^{\prime}$ and $28^{\circ} 44^{\prime} \mathrm{W}$ (Fig. 1, Table 1). Young Sound is a sill fjord (approximately $90 \mathrm{~km}$ long) located in NE Greenland. Summer (July and August) hydrographic conditions in the fjord are strongly affected by melting sea ice and freshwater inputs from melting snow and ice on land (Rysgaard et al. 1999, 2003, Bendtsen et al. 2014). A detailed description of fjord circulation processes can be found in Rysgaard \& Glud (2007) and Bendtsen et al. (2014). Water exchange between Young Sound and the offshore oceanic waters takes place during summer but is reduced by the shallow sill $(50 \mathrm{~m})$, which disconnects the deepest part of the fjord $(330 \mathrm{~m})$ from the waters of the EGC. The southward-flowing EGC is the main factor driving surface hydrographic conditions along the East Greenland coast. Large amounts of sea ice and pack ice are transported by the EGC from the Arctic Ocean, 
together with 'recirculating' Atlantic waters from the Fram Strait towards the Mid Denmark Strait (Aagaard \& Carmack 1989, Rudels et al. 2002, Rysgaard \& Glud 2007). Here, surface waters are also influenced by the Icelandic Irminger Current (IIC; Sutherland \& Pickart 2008).

\section{Sampling}

Pelagic sampling was conducted within Zackenberg Ecological Research Operations (ZERO), part of the GEM Programme, and during a research cruise on board the R/V 'Dana'. Samples were collected during a summer field campaign in the Young Sound fjord in July and August 2012 (fjord samples) and a research cruise in early September 2012 along the East Greenland coast (offshore samples). In addition, one station in Young Sound (Fig. 1, Table 1) was sampled 3 times each summer (July and August 2009 to 2012), providing data on inter-annual variability (time series samples).

Samples were collected at 20 stations ( 7 transects) using 2 sampling methods: net hauls and Niskin water bottles. Net haul samples were taken using a $20 \mu \mathrm{m}$ mesh net with a diameter of $25 \mathrm{~cm}$ and a length of $15 \mathrm{~cm}$ (KC Denmark). The net was submerged to $60 \mathrm{~m}$ water depth and towed vertically to the surface (potential sampled volume of $2.9 \mathrm{~m}^{3}$ tow $^{-1}$ ). Water bottle samples were taken using 101 Niskin bottles at the surface (5 to $10 \mathrm{~m}$ water depth) and deep chlorophyll maximum (DCM), then gently siphoned off using a silicon tube. Net haul samples

Fig. 1. Study site on the East Greenland coast with locations of sampling stations (red dots) during cruises in summer 2012 in (A) Young Sound and (B) Young Sound, Greenland Sea, Greenland Shelf and the Mid Denmark Strait. In Young Sound (A) separate regions are delimited with thick black lines and the monitoring station (std.DNB; time series data 2009-2012) is marked with an asterisk

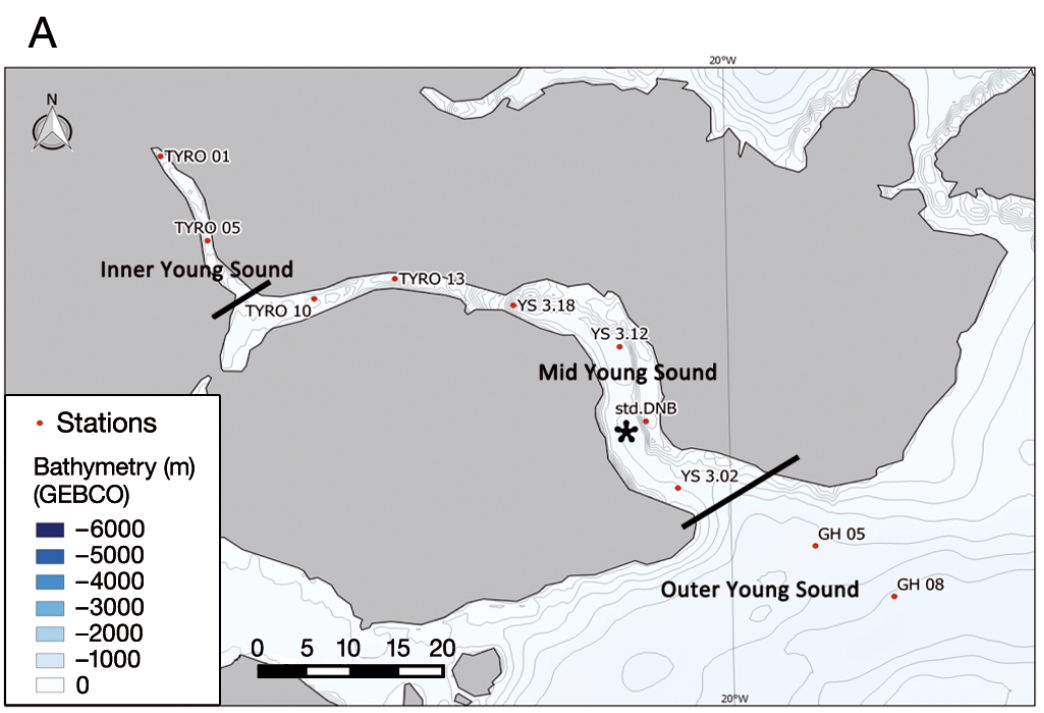

B

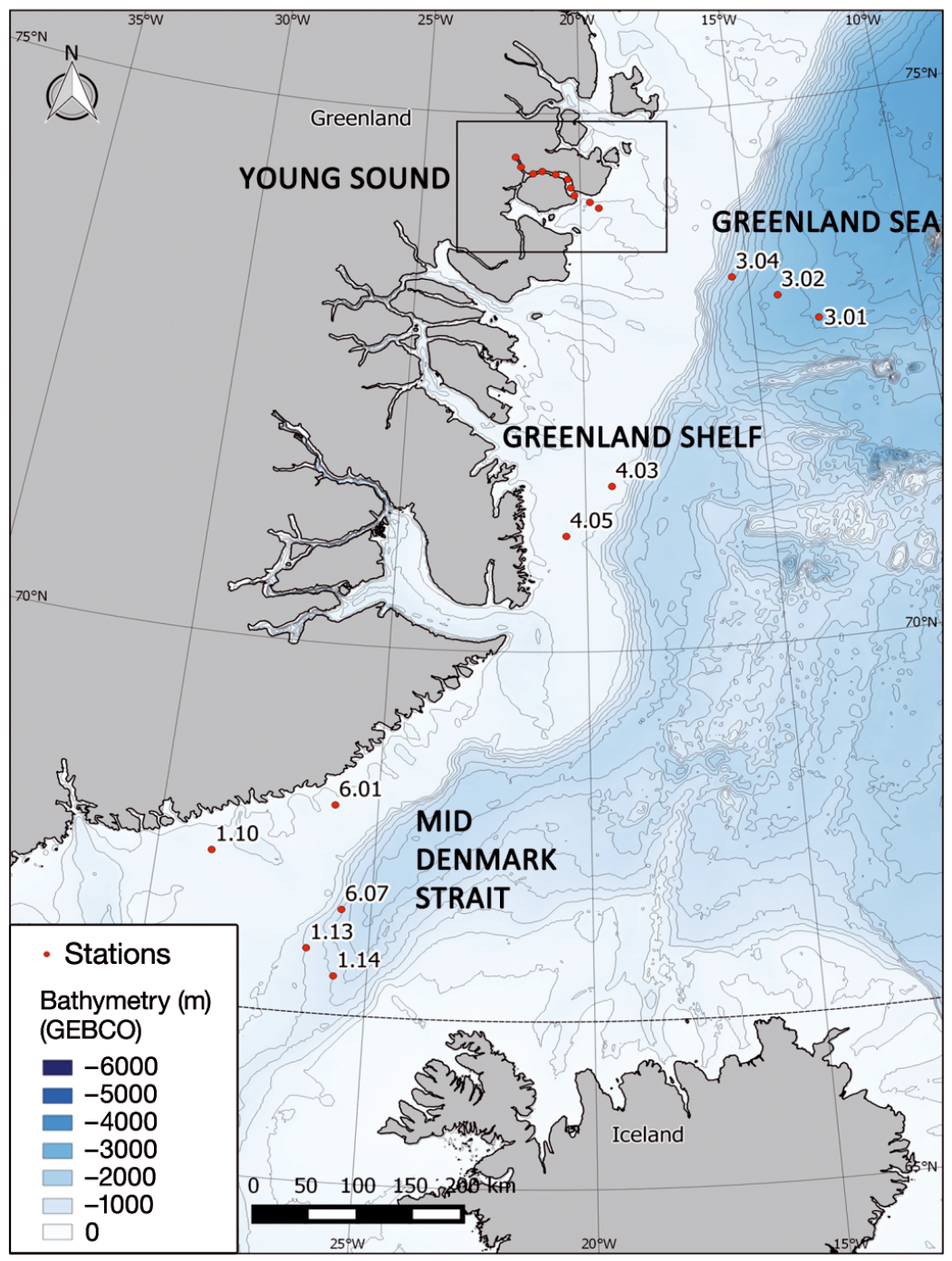


Table 1. Sampled stations and transects, their geographic positions, water depths and region. Time series were collected from Stn std.DNB (yyyy-sample no.); specific sampling dates (yyyy-mm-dd) are provided. For water bottles, sampled depths are surface waters and deep chlorophyll maximum (DCM)

\begin{tabular}{|c|c|c|c|c|c|c|c|c|}
\hline \multirow[t]{2}{*}{ Stn } & \multirow[t]{2}{*}{ Transect } & \multirow{2}{*}{$\begin{array}{l}\text { Latitude } \\
\text { (N) }\end{array}$} & \multirow{2}{*}{$\begin{array}{l}\text { Longitude } \\
\text { (W) }\end{array}$} & \multicolumn{2}{|c|}{$\longrightarrow$ Net hauls } & \multicolumn{2}{|c|}{$\begin{array}{l}\text { Water bottles } \\
\text { Sampling depth }(\mathrm{m})\end{array}$} & \multirow[t]{2}{*}{ Region } \\
\hline & & & & $\begin{array}{l}\text { Sampling } \\
\text { depth (m) }\end{array}$ & $\begin{array}{l}\text { No. of } \\
\text { replicates }\end{array}$ & $\begin{array}{l}\text { Sampling } \\
\text { Surface }\end{array}$ & $\begin{array}{l}\text { depth }(\mathrm{m}) \\
\text { DCM }\end{array}$ & \\
\hline 1.1 & 1 & $67^{\circ} 59^{\prime}$ & $28^{\circ} 44^{\prime}$ & $0-60$ & Duplicates & 10 & 40 & Mid Denmark Strait \\
\hline 1.13 & 1 & $67^{\circ} 09^{\prime}$ & $26^{\circ} 23^{\prime}$ & $0-60$ & Duplicates & 5 & 25 & Mid Denmark Strait \\
\hline 1.14 & 1 & $66^{\circ} 55^{\prime}$ & $25^{\circ} 44^{\prime}$ & $0-60$ & Duplicates & 5 & 32 & Mid Denmark Strait \\
\hline 3.01 & 3 & $72^{\circ} 57^{\prime}$ & $13^{\circ} 03^{\prime}$ & $0-60$ & Duplicates & 10 & 32 & Greenland Sea \\
\hline 3.02 & 3 & $73^{\circ} 12^{\prime}$ & $14^{\circ} 10^{\prime}$ & $0-60$ & Duplicates & 10 & 30 & Greenland Sea \\
\hline 3.04 & 3 & $73^{\circ} 24^{\prime}$ & $15^{\circ} 28^{\prime}$ & $0-60$ & Duplicates & 10 & 25 & Greenland Sea (sea ice edge) \\
\hline 4.03 & 4 & $71^{\circ} 32^{\prime}$ & $19^{\circ} 17^{\prime}$ & $0-60$ & Duplicates & 10 & 32 & Greenland Shelf \\
\hline 4.05 & 4 & $71^{\circ} 04^{\prime}$ & $20^{\circ} 32^{\prime}$ & $0-60$ & Duplicates & 5 & 32 & Greenland Shelf \\
\hline 6.01 & 6 & $68^{\circ} 30^{\prime}$ & $26^{\circ} 00^{\prime}$ & $0-60$ & Duplicates & 5 & 30 & Mid Denmark Strait \\
\hline 6.07 & 6 & $67^{\circ} 32^{\prime}$ & $25^{\circ} 40^{\prime}$ & $0-60$ & Duplicates & 10 & 33 & Mid Denmark Strait \\
\hline TYRO 01 & TYRO & $74^{\circ} 35^{\prime}$ & $22^{\circ} 04^{\prime}$ & $0-60$ & Duplicates & 5 & 5 & Inner Young Sound \\
\hline TYRO 05 & TYRO & $74^{\circ} 30^{\prime}$ & $21^{\circ} 53^{\prime}$ & $0-60$ & Duplicates & 5 & 5 & Inner Young Sound \\
\hline TYRO 10 & TYRO & $74^{\circ} 26^{\prime}$ & $21^{\circ} 30^{\prime}$ & $0-60$ & Duplicates & 5 & 20 & Mid Young Sound \\
\hline TYRO 13 & TYRO & $74^{\circ} 28^{\prime}$ & $21^{\circ} 12^{\prime}$ & $0-60$ & Duplicates & 5 & 20 & Mid Young Sound \\
\hline YS 3.18 & YS & $74^{\circ} 26^{\prime}$ & $20^{\circ} 46^{\prime}$ & $0-60$ & Duplicates & 5 & 30 & Mid Young Sound \\
\hline YS 3.12 & YS & $74^{\circ} 23^{\prime}$ & $20^{\circ} 23^{\prime}$ & $0-60$ & Duplicates & 5 & 20 & Mid Young Sound \\
\hline std.DNB & YS & $74^{\circ} 18^{\prime}$ & $20^{\circ} 18^{\prime}$ & $0-60$ & Duplicates $^{\mathrm{a}}$ & 5 & 30 & Mid Young Sound \\
\hline YS 3.02 & YS & $74^{\circ} 14^{\prime}$ & $20^{\circ} 11^{\prime}$ & $0-60$ & Duplicates & 5 & 20 & Mid Young Sound \\
\hline GH 05 & $\mathrm{GH}$ & $74^{\circ} 10^{\prime}$ & $19^{\circ} 42^{\prime}$ & $0-60$ & Duplicates & 5 & 30 & Outer Young Sound \\
\hline GH 08 & $\mathrm{GH}$ & $74^{\circ} 07^{\prime}$ & $19^{\circ} 25^{\prime}$ & $0-60$ & Duplicates & 5 & 20 & Outer Young Sound \\
\hline
\end{tabular}

were stored in $100 \mathrm{ml}$ amber glass bottles, and water bottle samples were stored in $250 \mathrm{ml}$ amber glass bottles, all of which contained acidic Lugol's solution to a final concentration of $1 \%$. A detailed list of positions, sampling methods, and exact sampled water depths (with number of net haul replicates) is provided in Table 1. Both of these sampling methods were applied to all sampled stations, except for the time series, where only net hauls were used. Profiles of temperature, salinity, chlorophyll a fluorescence, and irradiance (photosynthetically active radiation, 400 to $700 \mathrm{~nm}$ ) were registered in parallel with the plankton sampling, using a SBE19plus CTD profiler (SeaBird) equipped with a Seapoint chlorophyll a fluorometer and a 'biospherical-sensor'. In addition, water samples were collected using Niskin bottles for use in nutrient analyses, i.e. phosphate, $\mathrm{PO}_{4}{ }^{3-}$, silicic acid, $\mathrm{Si}(\mathrm{OH})_{4}$, and nitrate plus nitrite, $\mathrm{NO}_{3}{ }^{-}+\mathrm{NO}_{2}{ }^{-}$. Nutrient samples were taken at fixed water depths in Young Sound (1, 5, 10, 15, 20, 30, and $50 \mathrm{~m})$, while standard depths varied between stations in offshore waters but included 3 to 5 water depths in the upper $60 \mathrm{~m}$. Nutrient samples were kept frozen $\left(-20^{\circ} \mathrm{C}\right)$, then thawed slowly at $4^{\circ} \mathrm{C}$ over a period of $24 \mathrm{~h}$ prior to analysis. Nutrient concentrations were determined (1) for offshore samples using a Skalar autoanalyser (after Hansen \& Koroleff 1999), and (2) for Young Sound samples (including time series), $\mathrm{PO}_{4}{ }^{3}$, and $\mathrm{Si}(\mathrm{OH})_{4}$ concentrations using spectrophotometric methods (Grasshoff et al. 1983), while $\mathrm{NO}_{3}^{-}+$ $\mathrm{NO}_{2}{ }^{-}$concentrations were measured by vanadium chloride reduction (Braman \& Hendrix 1989). In addition, $\mathrm{Si}(\mathrm{OH})_{4}$ concentrations were corrected for varying salinity as suggested by Grasshoff et al. (1983). All measured variables for each station and date are presented in the Supplement at www.int-res.com/ articles/suppl/m538p099_supp.pdf.

\section{Sample processing}

A total of 114 samples, consisting of 76 net hauls (duplicates and triplicates) and 38 water bottles, were collected for the analysis of planktonic protists $(>20 \mu \mathrm{m})$. Sub-samples were examined using platecounting chambers in accordance with Utermöhl (1958). In each sub-sample, over 500 cells were counted using an inverted microscope. In these 
counts, we included colonies of the chrysophyte Dinobryon balticum and the centric diatom Chaetoceros cf. socialis $>20 \mu \mathrm{m}$ even though individual cells $<20 \mu \mathrm{m}$. In order to verify difficult diatom species or taxa, samples from selected stations (i.e. Young Sound, Greenland Sea, and time series) were rinsed, cleaned of organic material (using hydrogen peroxide), and mounted in Naphrax ${ }^{\circledR}$ for examination under light microscopy. Cells were identified to species based on Hasle \& Syvertsen (1996), Hasle \& Heimdal (1998), Quillfeldt (2001), Horner (2002), Throndsen et al. (2007), and Kraberg et al. (2010). All samples were counted by the same person to eliminate observer bias. The number of cells (including cells of colonies) in each sub-sample was calculated by multiplying the number of individuals counted in randomly distributed 'photomasks' (fields of view) by the ratio of the whole chamber area to the area of the counted photomasks. The taxonomic composition within the counted sub-sample was assumed to represent the taxonomic composition within the entire sample. The calculated number of cells from net haul sub-samples was averaged from the duplicates/ triplicates for each station/date.

\section{Data analysis}

Multivariate analyses were used to explore spatial and temporal distribution patterns in the taxonomic composition of the planktonic protists and were performed separately for net haul and water bottle samples. Relative abundances (i.e. net hauls) and absolute abundances (i.e. water bottles) of all taxa in pooled replicates were square-root transformed, and BrayCurtis similarities between samples (stations, depths, and dates) were depicted through ordination by nonmetric multidimensional scaling (nMDS) with cluster overlays based on hierarchical cluster analyses to complement the nMDS 2-D approximation using Primer v.6 software (Clarke \& Gorley 2006). The Bray-Curtis similarity $(S)$ between 2 samples ( $j$ and $k$ ) was defined as:

$$
S_{j \mathrm{k}}=100\left[1-\sum_{i=1}^{n}\left|y_{i j}-y_{i k}\right| / \sum_{i=1}^{n}\left(y_{i j}-y_{j k}\right)\right]
$$

where $y_{i j}$ and $y_{j k}$ are the square root-transformed (relative and absolute) abundances of taxa $i$ in samples $j$ and $k$, respectively. $S$ ranges from zero (no shared taxa) to 100 (identical samples). Analysis of similarity (ANOSIM) was used to test for differences in taxonomic composition between transects. ANOSIM R-statistics vary between 0 or even negative values (no differences in similarities between and within groups) and 1 (all similarities between samples from different groups, i.e. transects are smaller than any similarity among samples within groups). Average similarity percentages (SIMPER) were calculated to summarise patterns in taxonomic composition within and between groups of samples from different depths, stations, and transects, based on water bottle samples.

Canonical correspondence analysis (CCA) was used to analyse the relationships between measured variables, i.e. latitude, temperature, salinity, 'regional waters', nutrients, and planktonic protist taxa samples (i.e. stations, depths, and dates), based on net hauls and water bottle samples. 'Regional waters' represent averaged temperature and salinity values for each transect. All measured variables (except latitude) for net haul samples were averaged from 0 to $60 \mathrm{~m}$ water depths, while measured variables for water bottles were from surface waters and DCM (see the Supplement). The independence and relative strengths of individual variables were estimated using a series of partial CCAs (Borcard et al. 1992). Statistical significance ( $p$-values) of the relationship between samples and measured variables was evaluated using Monte Carlo permutation testing (1000 permutations). This analysis was carried out using the xlstat program (www.xlstat.com).

\section{RESULTS}

\section{Hydrography}

In summer 2012, water salinity and temperature in Young Sound changed significantly from the inner to the outer parts of the fjord. Low salinity (minimum of 4.2) and variable temperatures ( 0 to $12.4^{\circ} \mathrm{C}$ ) were recorded in the fjord surface waters (Fig. 2A). Surface water in the fjord is a mixture of meltwater from sea ice and freshwater from land. In addition, maximum concentrations of $\mathrm{Si}(\mathrm{OH})_{4}$ were recorded in the surface waters of inner Young Sound (see the Supplement). In contrast, higher salinity (max. 33.0) and low temperature (min. $-1.6^{\circ} \mathrm{C}$ ) were observed in subsurface waters, identified as Polar Surface Water (PSW; Fig. 2A). Surface water and PSW generally displayed higher salinity in East Greenland offshore waters relative to that in Young Sound. Modified Atlantic Water (MAW) was found in the Greenland Sea, with salinity $>34.2$ and temperature between 0 and $3.0^{\circ} \mathrm{C}$ (Fig. 2B). Here, the highest recorded water salinity (>34.2) was below approximately $25 \mathrm{~m}$. In the 


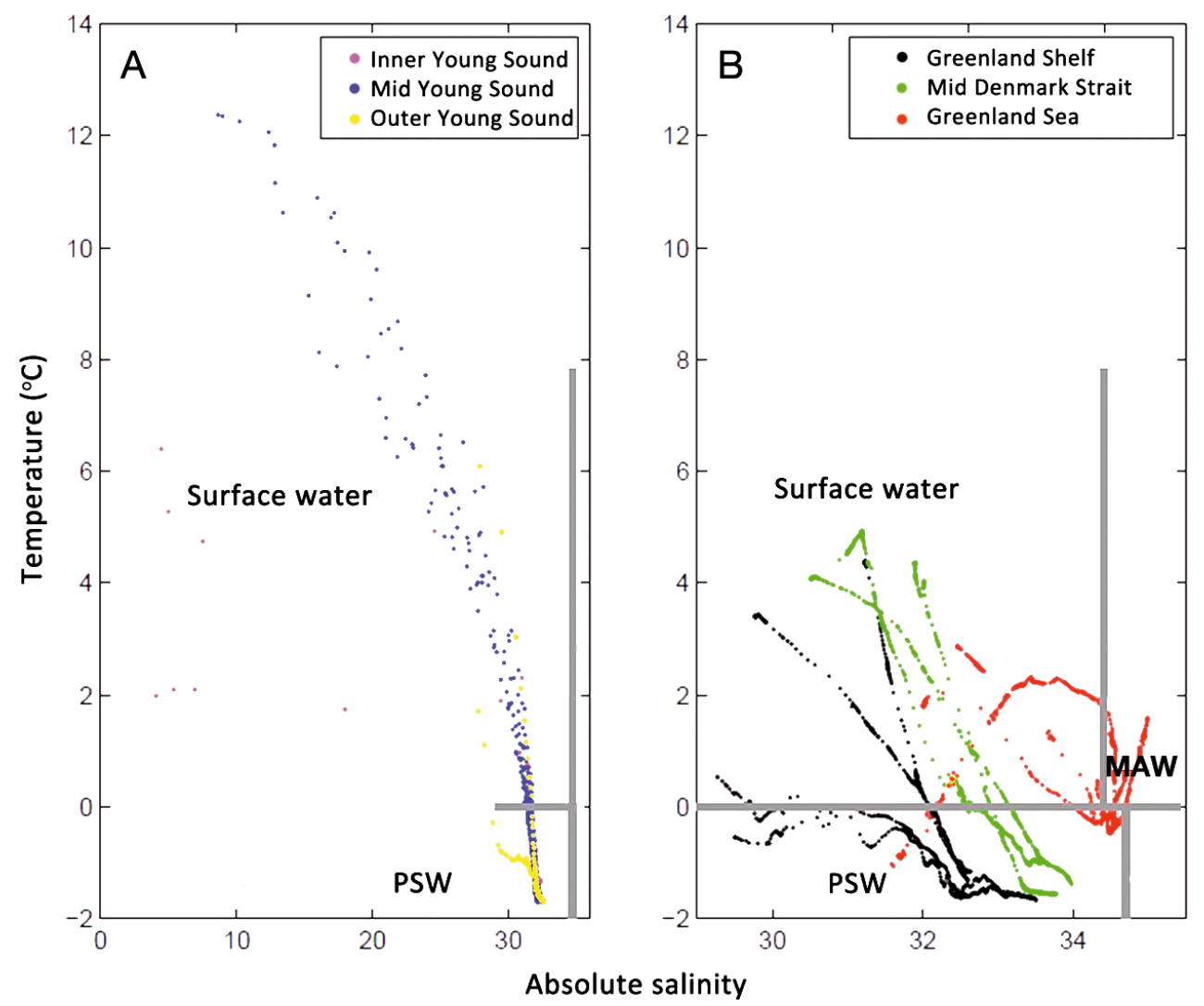

Fig. 2. Temperature versus absolute salinity (a more accurate representation of the salinity generated by the SBE 19 plus CTD profiler) (0-60 m water depth) from sampling stations. Water types (separated with thick grey lines) in (A) the fjord consisted of Surface water and Polar Surface Water (PSW) and (B) along the East Greenland coast consisted of Surface water, PSW, and Modified Atlantic Water (MAW)

Mid Denmark Strait, relatively high surface water temperature (up to $4.8^{\circ} \mathrm{C}$ ) was recorded compared to at other offshore sites (Fig. 2B).

\section{Planktonic protist assemblages $(>20 \mu \mathrm{m})$}

In total, 8 taxonomic groups (after Mees et al. 2015) were identified from net haul and water bottle samples: diatoms (Bacillariophyta), dinoflagellates (Dinoflagellata), ciliates (Ciliophora), silicoflagellates (Dictyochophyceae), chrysophytes (Chrysophyceae), chlorophytes (Chlorophyta), heliozoans (Heliozoa), and radiolarians (Radiolaria). A total of 108 taxa were identified to species level (mainly diatoms, due to cleaning) and 37 to genus or group level (mainly dinoflagellates, which are difficult to identify in Lugol's fixed samples). Diatoms were generally the most abundant group among the planktonic protists identified in the study.

Pairwise ANOSIM tests for differences in taxonomic abundances among all transects showed a clear regional separation of planktonic protist assemblages between fjord and offshore transects, i.e. high $\mathrm{R}$-statistics between fjord and offshore transects, and low R-statistics between transects within the fjord and offshore areas, respectively (Table 2). For water bottle samples, this difference in taxonomic absolute abundances in pairwise comparisons of offshore and fjord transects was statistically significant $(p<0.05)$ in all cases except one (from transect YS vs. Transect 4). While the tests on net haul samples gave similar R-statistics, thereby supporting the general distinction between fjord and offshore assemblages, significance levels for the net hauls were potentially biased by the lower number of samples (i.e. 1 depth stratum per station), and in most cases p-values were $>0.05$ for pairwise comparisons (data not shown). The nMDS plots for absolute and relative abundances of taxa also showed a general separation of the sampling stations into the Young Sound fjord waters on the one hand, and the offshore waters of the Greenland Sea, Greenland Shelf, and Mid Denmark Strait, on the other hand (Fig. 3). However, it also illustrates 
(1) relatively low similarities between depths at the same station (ranging between 7 and $76 \%$ ) and (2) higher similarities in taxonomic abundances within offshore waters compared to within-fjord waters. These results are summarised in Table 2A, which shows average similarities at different spatial scales, from within stations to between regions (fjord vs. offshore waters).

The nMDS plot of time series data (only net haul samples) from Young Sound (2009 to 2012) suggests a grouping of samples from the same years. The hierarchical clustering, illustrated with cluster overlays, supports this nMDS approximation, where 2009 is distinct from the other years (Fig. 4).

\section{Fjord waters}

Three separate distribution patterns in taxonomic composition of the planktonic protists were observed in Young Sound: inner, mid, and outer parts of the fjord (Figs. 3A \& 5A,B). The inner fjord waters were characterised by the highest relative abundances of chrysophyte colonies (average 57.5\%) and diatoms (average $23.5 \%$ ), based on net hauls (Fig. 5A). Chrysophytes were represented by Dinobryon balticum, which reached a maximum of $79.6 \%$ at Stn TYRO 05 (Fig. 5A). Diatoms were represented mainly by Melosira arctica (Table 3), which was only observed in Young Sound. However, neither $D$. balticum nor $M$. arctica were found in surface waters or the DCM (both $5 \mathrm{~m}$ ) from water bottle samples (Fig. 5B). The mid-section of the fjord was characterised by a dominance of diatoms (average $62.8 \%$ ) and dinoflagellates (average $24.4 \%$ ), based on net hauls (Fig. 5A). Similar taxonomic composition was recorded from water bottles (Fig. 5B). Here, diatoms showed the highest recorded absolute abundance in DCM at Stn TYRO 13 (57834 cells 1 ${ }^{-1}$ ) throughout the study (Fig. 5B). Data from both net haul and water bottle samples showed that diatoms were represented mainly by Fragilariopsis sp. (Table 3). The taxonomic composition of outer Young Sound showed a dominance of diatoms based on both net hauls and water bottle samples (average 97.8\% and 18475 cells $1^{-1}$, respectively; Fig. 5A,B). The highest absolute abundances of diatoms were recorded in DCMs (Fig. 5B). This planktonic protist group was represented mainly by the genus Fragilariopsis, e.g. F. oceanica (Table 3).

\section{Offshore waters}

Along the East Greenland coast, the planktonic protist assemblage was mainly comprised of diatoms (average $61.0 \%$ ) and silicoflagellates (average 12.6\%) based on net hauls (Figs. 5C \& 6A,C) but of diatoms

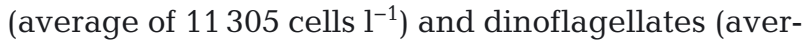

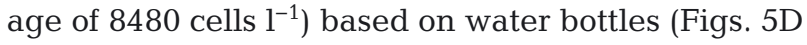
\& 6B,D). Minor groups, such as colonial chrysophytes, were recorded in net hauls alone (Fig. 6C). 

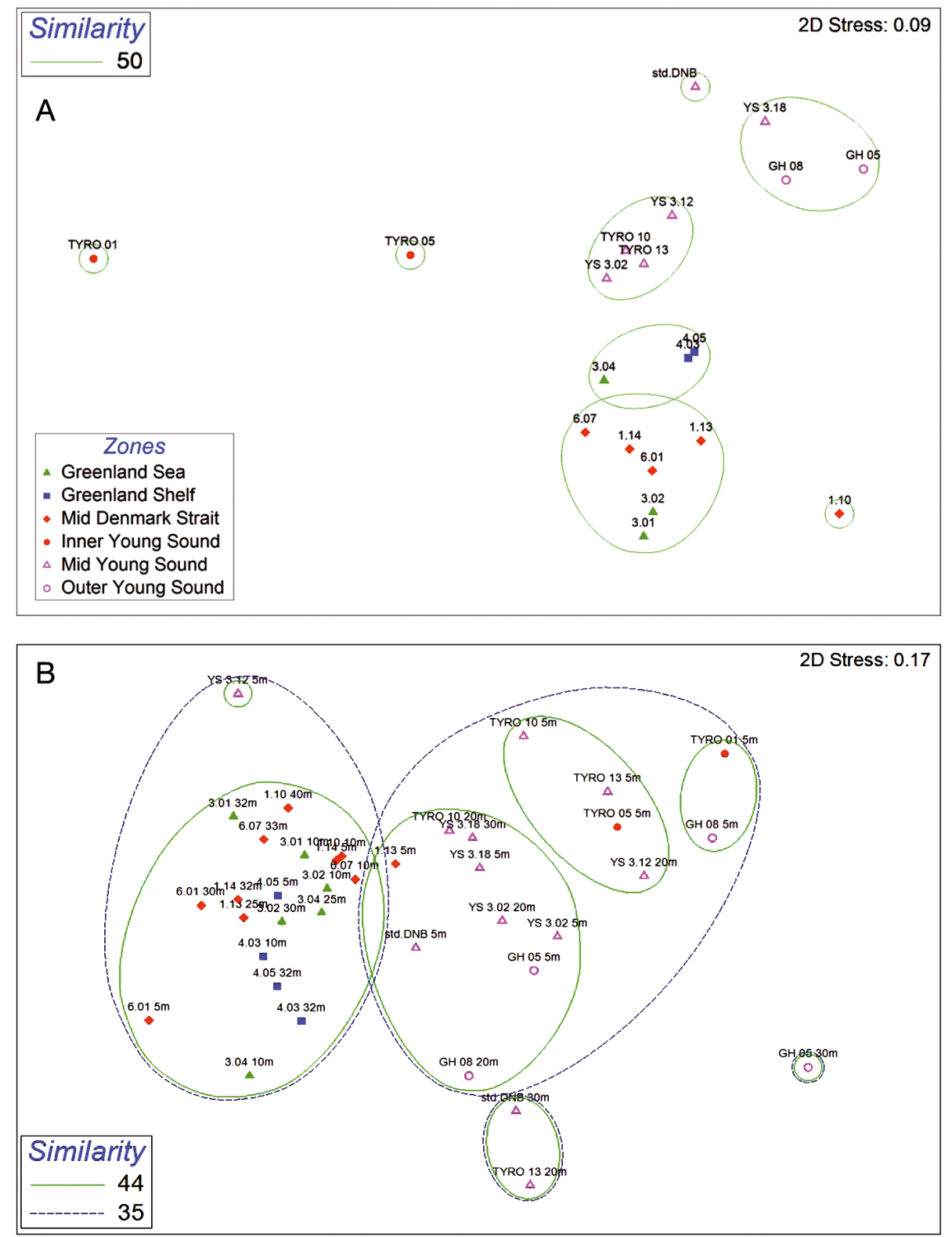

Fig. 3. Non-metric multidimensional scaling (nMDS) ordination diagrams for square-root transformed data of planktonic protist taxa. (A) Relative abundances of taxa for each sampling station based on net hauls, and (B) absolute abundances of taxa for each sampling station and depth based on water bottles. Overlays (contour lines) display clusters of different similarity levels resulting from hierarchical cluster analyses. The nMDS diagrams are based on Bray-Curtis similarities, whereby the distance between samples in the plot reflects their similarity (\%) in taxonomic composition

Near-coast waters of the Greenland Shelf showed the highest (relative and absolute) abundances of diatoms (Fig. 5C,D), with an average of $71.8 \%$ from net hauls and average of 14071 cells $^{-1}$ from water bottles, and were dominated by Eucampia groenlandica (Table 3). The offshore waters of the Greenland Sea showed a dominance of diatoms (average 50.0\%) and silicoflagellates (average $20.0 \%$ ), based on net hauls (Fig. 6A). Diatoms were mainly represented by the genus Chaetoceros while silicoflagellates were represented by Dictyocha speculum (Table 3). The latter group showed the highest relative abundances at Stns 3.02 and 3.01 (35.0 and $22.0 \%$, respectively; Fig. 6A). Although silicoflagellates recorded a maxi-

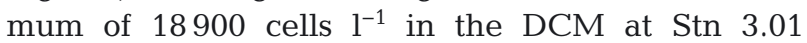
(Fig. 6B), the water bottle samples were generally dominated by dinoflagellates, which were represented by naked dinoflagellates and Gyrodinium spi- 


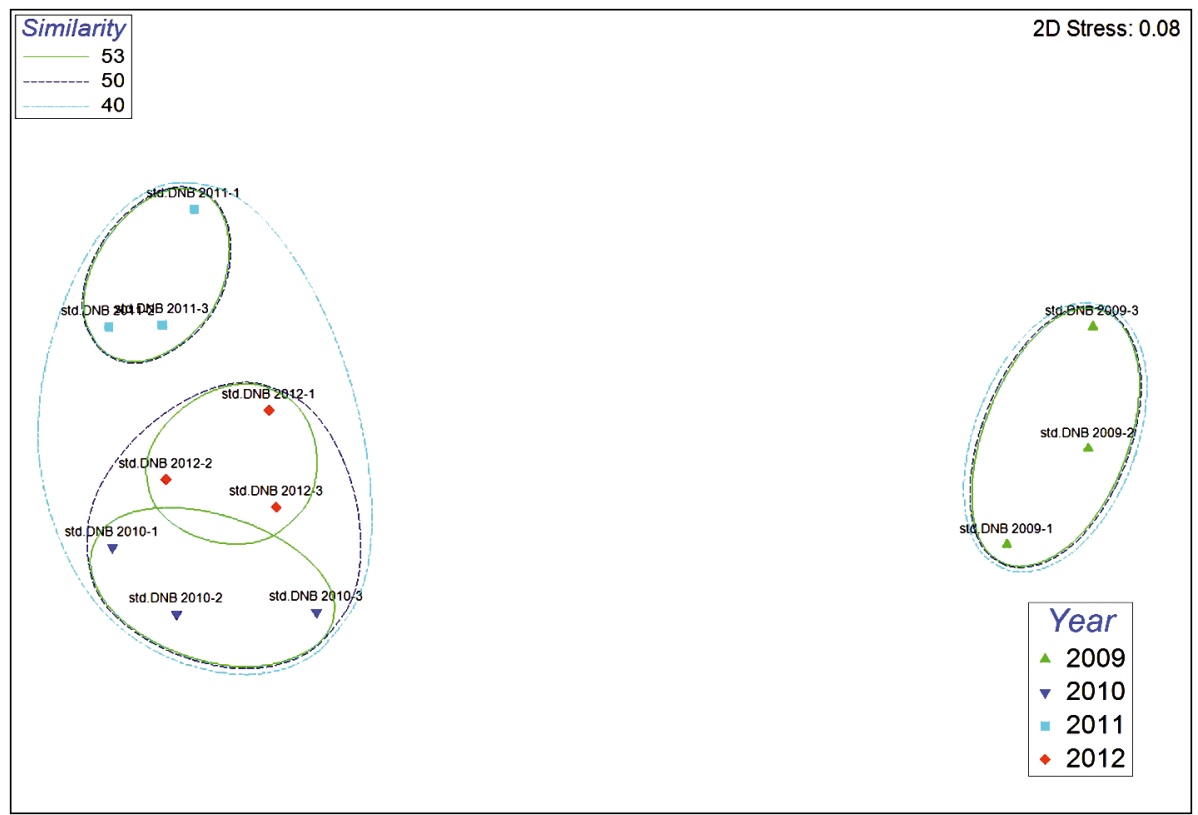

Fig. 4. Non-metric multidimensional scaling (nMDS) ordination diagrams for square-root transformed data of planktonic protist taxa at a monitoring station in the entrance of Young Sound fjord (std.DNB). Relative abundances of taxa are presented for each sampling date based on net hauls. The nMDS diagrams are based on BrayCurtis similarities, where distance between samples in the plot reflects their similarity in taxonomic composition. Samples are named according to the order of sampling date (i.e. std.DNB yyyy-sample no.; see Table 1. The overlays (contour lines) display clusters of different similarity levels resulting from a hierarchical cluster analysis

rale (Table 3). The waters of the Mid Denmark Strait were characterised by a dominance of diatoms and dinoflagellates, based on both net hauls and water bottles (Fig. 6C,D). Nevertheless, silicoflagellates also showed high relative abundances in net haul samples (average 12.0\%; Fig. 6C). Data combined from net hauls and water bottles showed that the diatom genus Chaetoceros represented planktonic protists in these waters, though the diatom genus Rhizosolenia (e.g. R. hebetata) also contributed significantly (Table 3$)$.

\section{Internal comparisons}

The time series (2009 to 2012) of planktonic protist assemblages collected by net hauls in mid Young Sound showed a general dominance of diatoms (average $92.2 \%$ ) and fewer colonial chrysophytes (average $5.7 \%$ ). The highest relative abundance of diatoms was observed in 2010 (average 99.0\%; Fig. 7B). The diatom genus Chaetoceros dominated in 2009 and 2011 while the genus Fragilariopsis dominated in 2010 and in 2012 (Table 3). The former genus was represented by $C$. decipiens, while the latter was represented by $F$. oceanica and F. cylindrus (Table 3 ). Chrysophytes (D. balticum) contributed significantly to the planktonic protist assemblage in 2009 (average 21.7\%; Fig. 7A). However, $D$. balticum was observed neither in the summer of 2011 nor in 2 sampling days in 2010 and 2012 (Fig. 7).

\section{Relationship between planktonic protists and environment}

Relationships between planktonic protists and the measured variables (i.e. latitude, temperature, salinity, and regional waters) were investigated using 2 sampling methods. The ordination diagrams of the spatial data (measured variables, taxa $>1 \%$, and sample values) along the CCA axes are shown separately for net hauls and water bottles (Figs. $8 \& 9$, respectively). On the biplot, the direction of the variables' lines represents their correlation with the ordination axis, other variables, taxa, and samples. Temperature and regional waters were negatively correlated with Axis 1, latitude was positively correlated with Axis 1, and salinity was correlated with Axis 2-negatively for net hauls and positively for water bottles. Generally, samples (with representative taxa) from Young Sound and the Greenland Shelf were influenced by high-latitude, cold, and low-salinity waters. In contrast, samples from the Greenland Sea were influenced by more saline oceanic waters, and those from the Mid Denmark Strait were influenced by warmer oceanic waters (Figs. 8 \& 9). The measured variables explained $32.0 \%$ of the variance in planktonic protist data based on net hauls and $28.0 \%$ based on water bottles (Table 4A). The partial CCAs showed that the most significant individual variables were regional waters, latitude, and temperature. Nutrients were tested separately along with latitude, temperature, salinity, and regional waters, excluding most Mid Denmark 
Young Sound

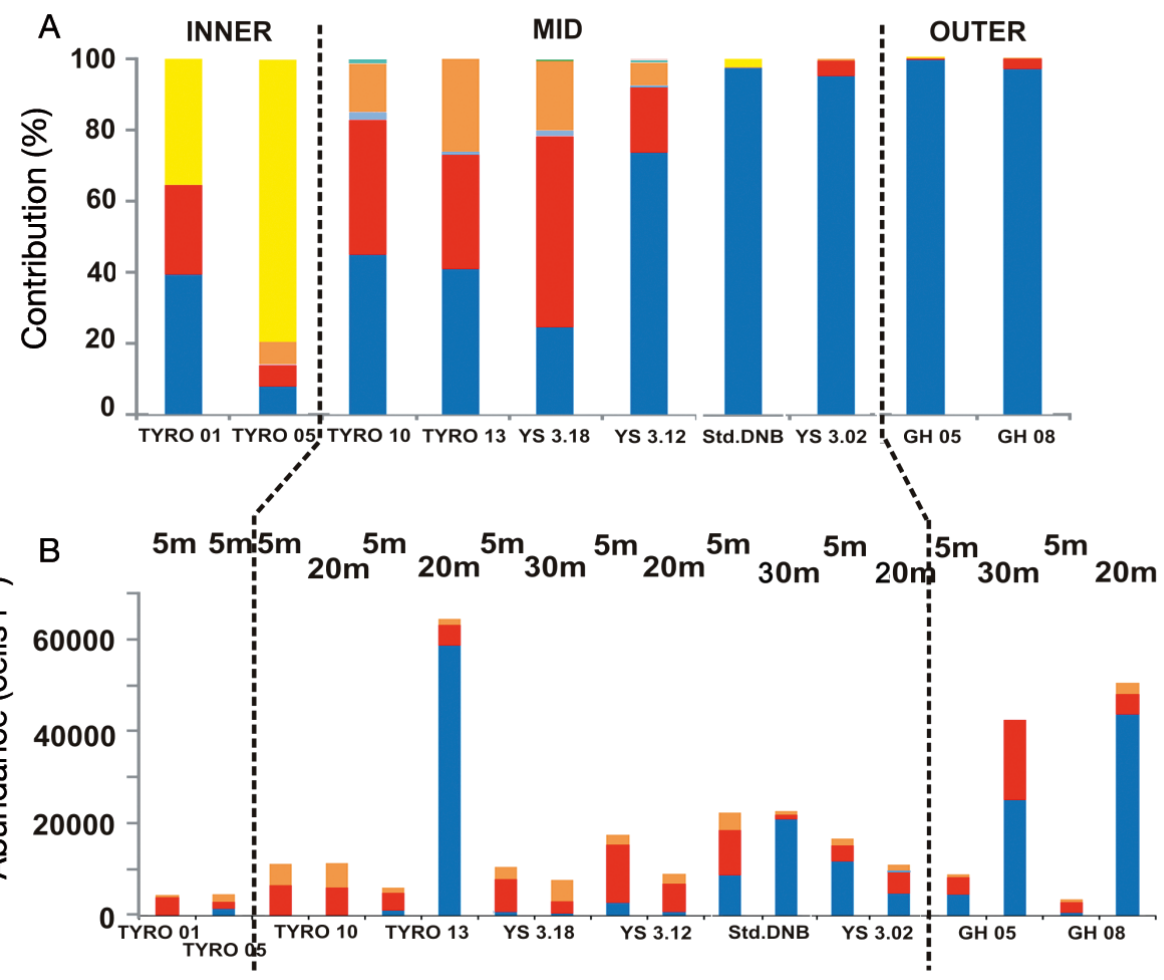

$$
\begin{aligned}
& \text { Radiolarians } \\
& \text { Heliozoans } \\
& \text { = Chlorophytes } \\
& =\text { Chrysophytes } \\
& =\text { Ciliates } \\
& =\text { Silicoflagellates } \\
& \text { = Dinoflagellates } \\
& \text { = Diatoms }
\end{aligned}
$$

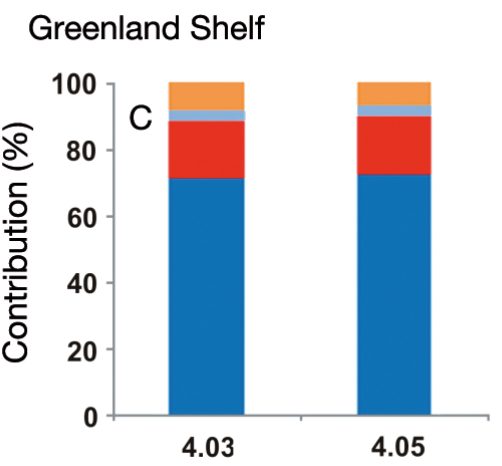

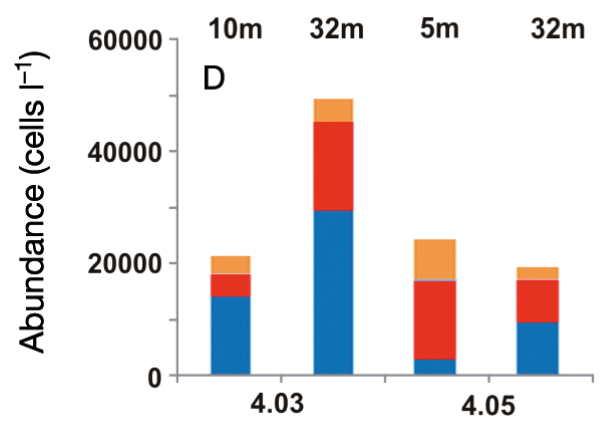

Fig. 5. Spatial distribution patterns of the planktonic protist assemblages at sampling stations in $(\mathrm{A}, \mathrm{B})$ Young Sound, based on (A) net hauls (\%) and (B) water bottles (cells $1^{-1}$ ) and in (C,D) Greenland Shelf, based on (C) net hauls (\%) and (D) water bottles (cells $\mathrm{l}^{-1}$ ). Water bottles were taken from surface waters and deep chlorophyll maximum (depths marked on figure).

Stations indicated on $x$-axis
Strait stations, where nutrients were not measured (Table 4B). This analysis showed that salinity, regional waters, and $\mathrm{Si}(\mathrm{OH})_{4}$ were most significant for taxonomic composition based on net hauls, but that only regional waters was significant based on water bottle samples. In particular, net haul samples from inner Young Sound was influenced by low-salinity waters along with higher concentrations of $\mathrm{Si}(\mathrm{OH})_{4}$ (data not shown).

The partial CCA of time series data (taxa $>1 \%$ ) showed no significant correlation with individual variables, though combined temperature, salinity, and nutrients, explain $58.5 \%$ of the variance in planktonic protist data (Table $4 \mathrm{C}$ ).

\section{DISCUSSION}

The summer (2012) planktonic protists (>20 $\mu \mathrm{m})$ from East Greenland waters show 2 distribution patterns: fjord assemblages represented mainly by 'sea ice-associated' diatoms and colonial chrysophytes, and offshore assemblages represented by diatoms, silicoflagellates, and dinoflagellates. Within fjord waters, planktonic protists showed inter-annual variation on the basis of time series data (2009 to 2012). In the following sections, we first compare and discuss the 2 applied sampling methods and then describe spatial and temporal distribution patterns of planktonic protists. 
Table 3. Most abundant taxa ( $>1 \%$ ) from net hauls and water bottles with average relative occurrence at sampled regions and years. Empty cells: no occurrence; $(-)<1 \%$; (+) 1-10\%; (++) 10-50\%; (+++) >50\% (dominance). DT: diatoms; DF: dinoflagellates; SL: silicoflagellates; CL: ciliates; CH: chrysophytes. YS: Young Sound; GS: Greenland Sea; GSh: Greenland Shelf; DS:Denmark Strait

\begin{tabular}{|c|c|c|c|c|c|c|c|c|c|c|c|}
\hline Group & Taxon & $\begin{array}{c}\text { Inner } \\
\text { YS }\end{array}$ & $\begin{array}{l}\text { Mid } \\
\text { YS }\end{array}$ & $\begin{array}{c}\text { Outer } \\
\text { YS }\end{array}$ & GS & GSh & $\begin{array}{c}\text { Mid } \\
\text { DS }\end{array}$ & $\begin{array}{c}\text { Mid } \\
\text { YS } \\
2009\end{array}$ & $\begin{array}{c}\text { Mid } \\
\text { YS } \\
2010\end{array}$ & $\begin{array}{c}\text { Mid } \\
\text { YS } \\
2011\end{array}$ & $\begin{array}{c}\text { Mid } \\
\text { YS } \\
2012\end{array}$ \\
\hline \multicolumn{12}{|c|}{ Net hauls } \\
\hline DT & Chaetoceros borealis Bailey & & & - & ++ & - & + & + & & & \\
\hline DT & Chaetoceros cf. socialis Lauder & & + & & & & + & + & - & + & + \\
\hline DT & Chaetoceros decipiens Cleve & & + & + & + & ++ & ++ & ++ & + & + & - \\
\hline DT & Chaetoceros sp. & + & + & & ++ & ++ & - & + & + & +++ & + \\
\hline DT & Eucampia groenlandica Cleve & - & + & ++ & - & ++ & - & + & + & + & ++ \\
\hline DT & Fragilariopsis cylindrus (Grunow) Krieger & & & + & & & & + & ++ & + & + \\
\hline DT & Fragilariopsis oceanica (Cleve) Hasle & & + & + & & & & - & ++ & + & ++ \\
\hline DT & Fragilariopsis sp. & - & ++ & ++ & - & & & & + & & - \\
\hline DT & Melosira arctica Dickie & ++ & - & - & & - & - & - & & & - \\
\hline DT & Navicula sp. & & + & - & - & - & - & - & + & - & ++ \\
\hline DT & Pauliella taeniata (Grunow) Round \& Basson & & + & + & & & & + & + & + & + \\
\hline DT & Rhizosolenia hebetata Bailey & & & - & - & - & + & & & - & \\
\hline DT & Rhizosolenia sp. & & & & - & - & ++ & & & & \\
\hline DT & $\begin{array}{l}\text { Thalassiosira antarctica var. borealis Fryxell, } \\
\text { Ducette et Hubbard }\end{array}$ & & + & + & - & - & + & + & + & + & + \\
\hline $\mathrm{DF}$ & Alexandrium sp. & & + & & - & - & + & - & - & - & - \\
\hline DF & Protoperidinium brevipes (Paulsen) Balech & + & + & - & - & - & - & - & - & - & - \\
\hline $\mathrm{DF}$ & Protoperidinium sp. & + & ++ & - & + & ++ & + & - & - & - & - \\
\hline $\mathrm{DF}$ & Scrippsiella trochoidea (Stein) Balech ex Loeblich III & + & - & & & & - & & & - & \\
\hline SL & Dictyocha speculum Ehrenberg & - & - & - & ++ & + & ++ & - & - & - & - \\
\hline CL & Acanthostomella norvegica Daday (Jorgensen) & - & + & - & + & + & + & - & - & - & - \\
\hline CL & Favella serrata (Möbius) Jörgensen & - & + & & + & - & + & - & - & & \\
\hline CL & Parafavella denticulata (Ehrenberg) Kofoid \& Campbell & & & & + & + & + & - & - & & \\
\hline $\mathrm{CH}$ & Dinobryon balticum (Schütt) Lemmermann & +++ & - & - & & & + & ++ & - & & - \\
\hline \multicolumn{12}{|c|}{ Water bottles } \\
\hline DT & Chaetoceros cf. socialis & & + & & ++ & + & ++ & & & & \\
\hline DT & Chaetoceros decipiens & & & + & + & & + & & & & \\
\hline DT & Chaetoceros diadema (Ehrenberg) Gran & & & & ++ & + & ++ & & & & \\
\hline DT & Chaetoceros sp. & ++ & + & + & - & & - & & & & \\
\hline DT & Coscinodiscus sp. & & + & + & ++ & ++ & + & & & & \\
\hline DT & Eucampia groenlandica & & + & - & + & ++ & - & & & & \\
\hline DT & Fragilariopsis oceanica & & & ++ & & & & & & & \\
\hline DT & Fragilariopsis sp. & & ++ & ++ & & & ++ & & & & \\
\hline DT & Nitzschia frigida Grunow & & ++ & - & & & & & & & \\
\hline DT & Pseudo-nitzschia sp. & ++ & + & & + & - & - & & & & \\
\hline DT & Thalassiosira/Actinocyclus sp. & & - & + & - & - & - & & & & \\
\hline $\mathrm{DF}$ & Gyrodinium cf. spirale (Bergh) Kofoid \& Swezy & & + & + & ++ & ++ & ++ & & & & \\
\hline $\mathrm{DF}$ & Naked dinoflagellates & & + & + & ++ & + & ++ & & & & \\
\hline DF & Protoperidinium sp. & +++ & + & ++ & + & + & + & & & & \\
\hline SL & Dictyocha speculum & & - & & ++ & - & + & & & & \\
\hline CL & Strombidium sp. & + & + & + & ++ & + & ++ & & & & \\
\hline CL & Tintinnopsis sp. & + & + & & + & + & - & & & & \\
\hline
\end{tabular}

\section{Sampling methods}

The 2 sampling methods applied in this study (net hauls and Niskin water bottle samples) showed statistically significant changes in taxonomic composition using multivariate data analyses. Regional separation of samples into fjord and offshore waters was similar for both sampling methods based on nMDS plots
(Figs. 3 \& 4, Table 2). Both methods also presented similar variations in planktonic protist assemblages, i.e. high variation in the Young Sound waters depicting 3 separate types of assemblages, with a small variation in offshore waters. Both methods showed similar distributions of taxa and samples relative to measured variables on the CCA plots. Among these variables, regional waters, latitude, and temperature 


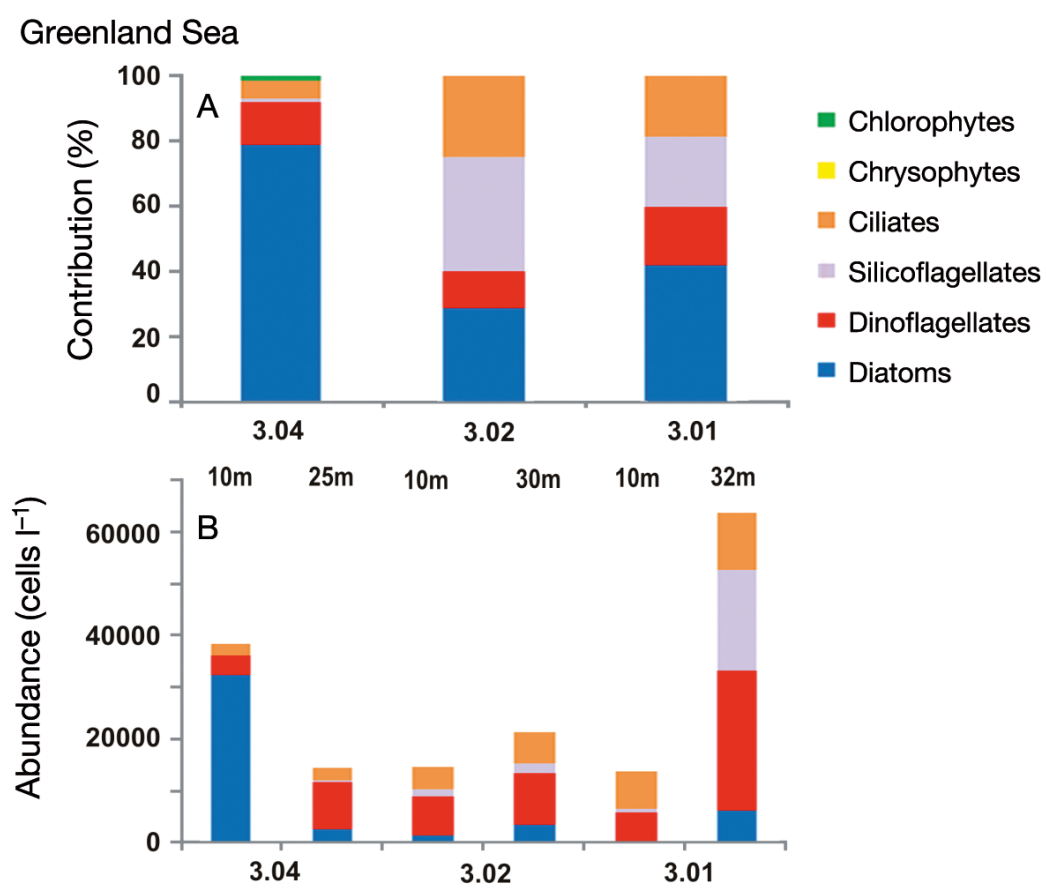

Mid Denmark Strait

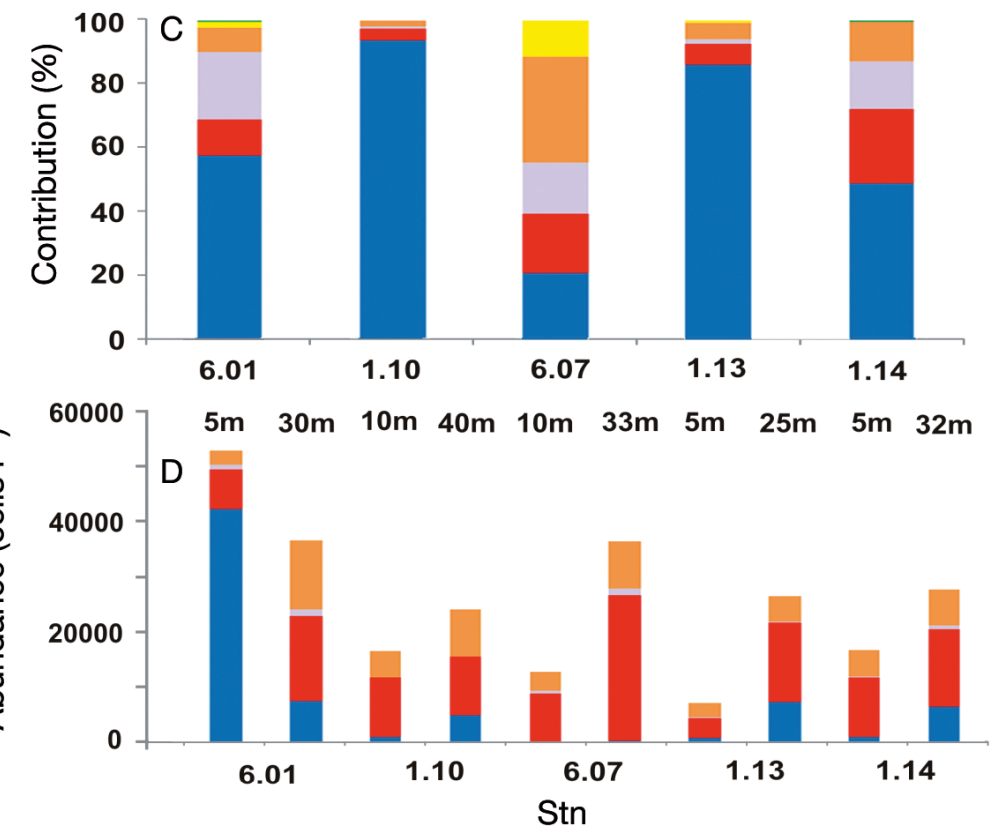

Fig. 6. Spatial distribution patterns of the planktonic protist assemblages at sampling stations in $(A, B)$ Greenland Sea and in $(C, D)$ Mid Denmark Strait, based on $(\mathrm{A}, \mathrm{C})$ net hauls $(\%)$ and $(\mathrm{B}, \mathrm{D})$ water bottles $\left(\right.$ cells $\left.\mathrm{l}^{-1}\right)$. Water bottles were taken from surface waters and deep chlorophyll maximum (depths marked on figure)

primarily explained the variation in the planktonic protist assemblages (Figs. $8 \&$ 9, Table 4). However, these factors explained more variation among taxa in the dataset from the net hauls and showed more significance per individual variable compared to data from the water bottles. This is most likely due to the higher numbers of cells in the net haul samples, in agreement with Rodríguez-Ramos et al. (2014), who argue that conventional Utermöhl method of counting of water samples often underestimates species richness. Nevertheless, both methods indicated that most of the variance was unexplained (68 to $72.0 \%$ ) by the measured variables.

On the other hand, an important planktonic protist group (i.e. colonial chrysophytes) found in samples from net hauls was not observed in any samples from the surface or in the DCM from water bottles (Figs. 5 \& 6). In addition, in offshore waters the planktonic protist assemblage was represented by diatoms and dinoflagellates in the case of water bottles and by diatoms and silicoflagellates in the case of net hauls. In offshore waters, the photic zone encompasses the upper $60 \mathrm{~m}$ water depth, which means that all taxa found in both net haul samples (0 to $60 \mathrm{~m}$ water depth) and water bottle samples (surface waters and DCM) are within the photic zone. These afore-mentioned observations suggest a vertical variation among chrysophytes, dinoflagellates, and silicoflagellates, possibly occurring at different depth ranges. The 2 water depths sampled at each station may therefore be insufficient for describing the vertical richness among planktonic protists along the East Greenland coast. The common practice of using only a few selected depths in many plankton studies may therefore be insufficient for establishing the full plankton food web diversity. However, it should be noted that some taxa dominant in water bottle samples-particularly delicate cells such as naked dinoflagellates - were only a minor component of net haul samples, probably due to mechanical stress destroying cells during net hauling and/or different proportions of taxa occurring in different depth ranges. Water bottle data also indicated a wide variation in taxonomic composition within 2 sampled water 

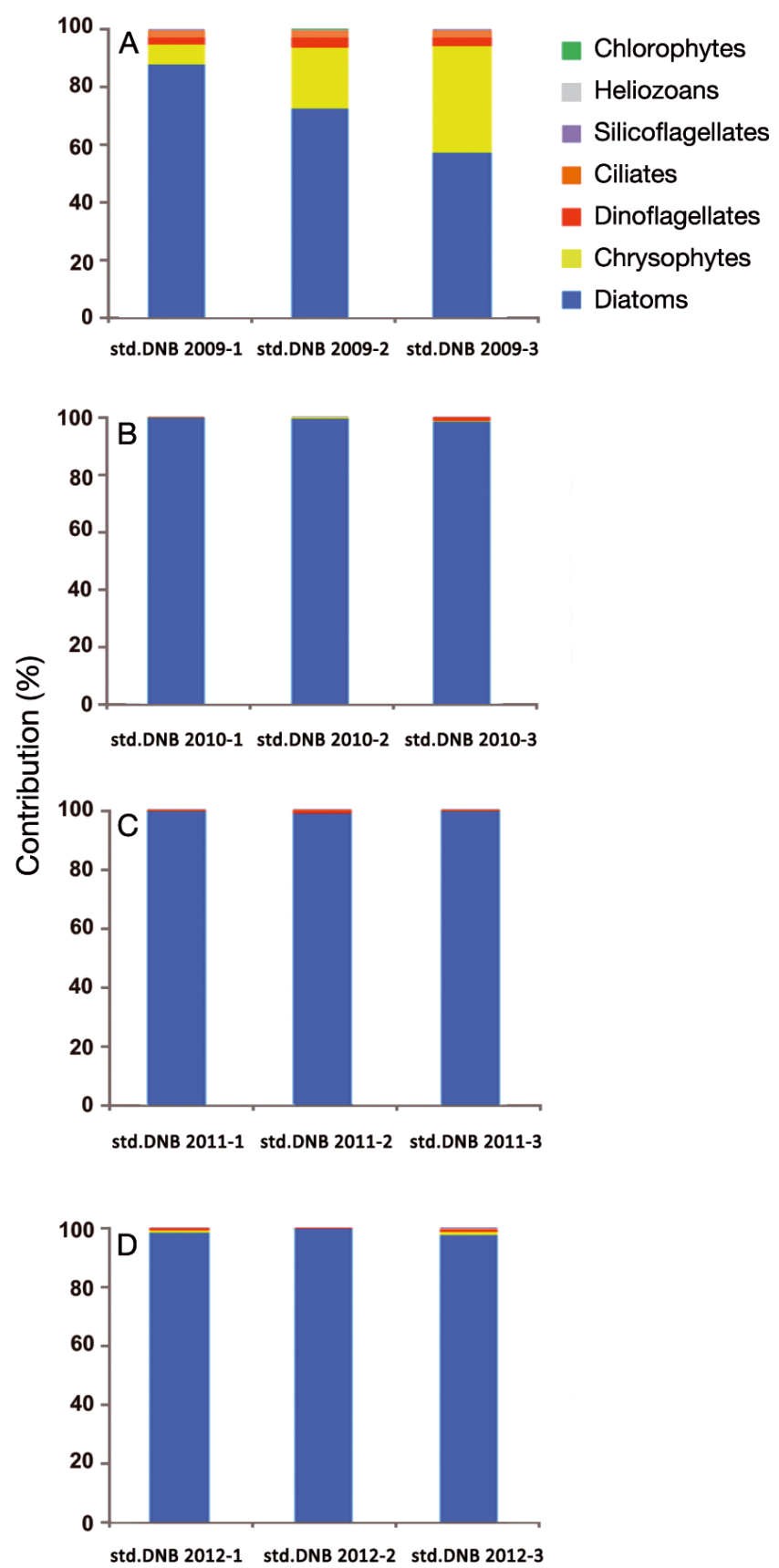

Fig. 7. Temporal patterns of the planktonic protist assemblages (\%) in mid Young Sound based on net hauls in (A) 2009, (B) 2010, (C) 2011, and( D) 2012. $x$-axis shows the monitoring station std.DNB, year of sampling and sampling no.

depths at the same station, particularly in fjord waters. This wide variation between depths might be caused by distinct surface water layering, particularly in Young Sound fjord waters during the sampled summer season.

In summary, we found that both of the applied sampling methods were statistically valid and comple- mented each other, with water bottle samples producing quantitative/qualitative data and net haul samples only qualitative data in this study. Net hauls nevertheless seemed to provide more statistically important information on planktonic protist composition, richness, and relationship with the environment, whereas water bottles provided more statistically important information on variation among taxa on different spatial scales between depths and between regions.

\section{Fjord waters}

In Young Sound, melting sea ice and freshwater inputs from land govern the temperature and salinity gradient between the inner and outer parts of the fjord. Such a gradient in high Arctic fjords triggered by glacial discharge is known to affect plankton species richness and abundance (Keck et al. 1999, Strom et al. 2006). The summer gradient in Young Sound fjord waters most likely drives the high variation in the planktonic protist assemblage, which shows 3 separate distribution patterns.

Colonies of chrysophytes (i.e. Dinobryon balticum) and the diatom Melosira arctica characterised the inner fjord waters along with the lowest recorded salinity. $D$. balticum is regarded as preferring low-saline summer surface waters in sub-Arctic and Arctic fjords (Hasle \& Heimdal 1998, Krawczyk et al. 2015). M. arctica was recorded only in inner Young Sound throughout the study and is commonly found attached to sea ice or in the plankton under or in the vicinity of ice (Hasle \& Syvertsen 1996). M. arctica was accordingly reported in ice floes in the Fram Strait (Gradinger \& Baumann 1991) and in the West Greenland marginal sea ice area north of $70^{\circ} \mathrm{N}$ (Krawczyk et al. 2014). Such taxonomic composition associated with low-salinity and cooler waters reflects summer melting of sea ice and strong terrestrial runoff. Strong freshwater input delivers loads of silt, carrying $\mathrm{Si}(\mathrm{OH})_{4}$ to the surface waters of the inner fjord. Generally, diatoms and colonial chrysophytes are common components of sub-Arctic and Arctic summer waters (Hasle \& Heimdal 1998, Okolodkov et al. 2000, Krawczyk et al. 2015). The low-salinity but warmer waters recorded in mid Young Sound indicate summer heating of the fresher surface waters as these waters are transported out of the fjord. Waters here are characterised by the diatom genus Fragilariopsis and dinoflagellates. The genus Fragilariopsis is often associated with melting sea ice but also appears in ice-free, open marine waters (Hasle \& Syvertsen 1996, Quillfeldt 1996, 2001, 2005) and is a 

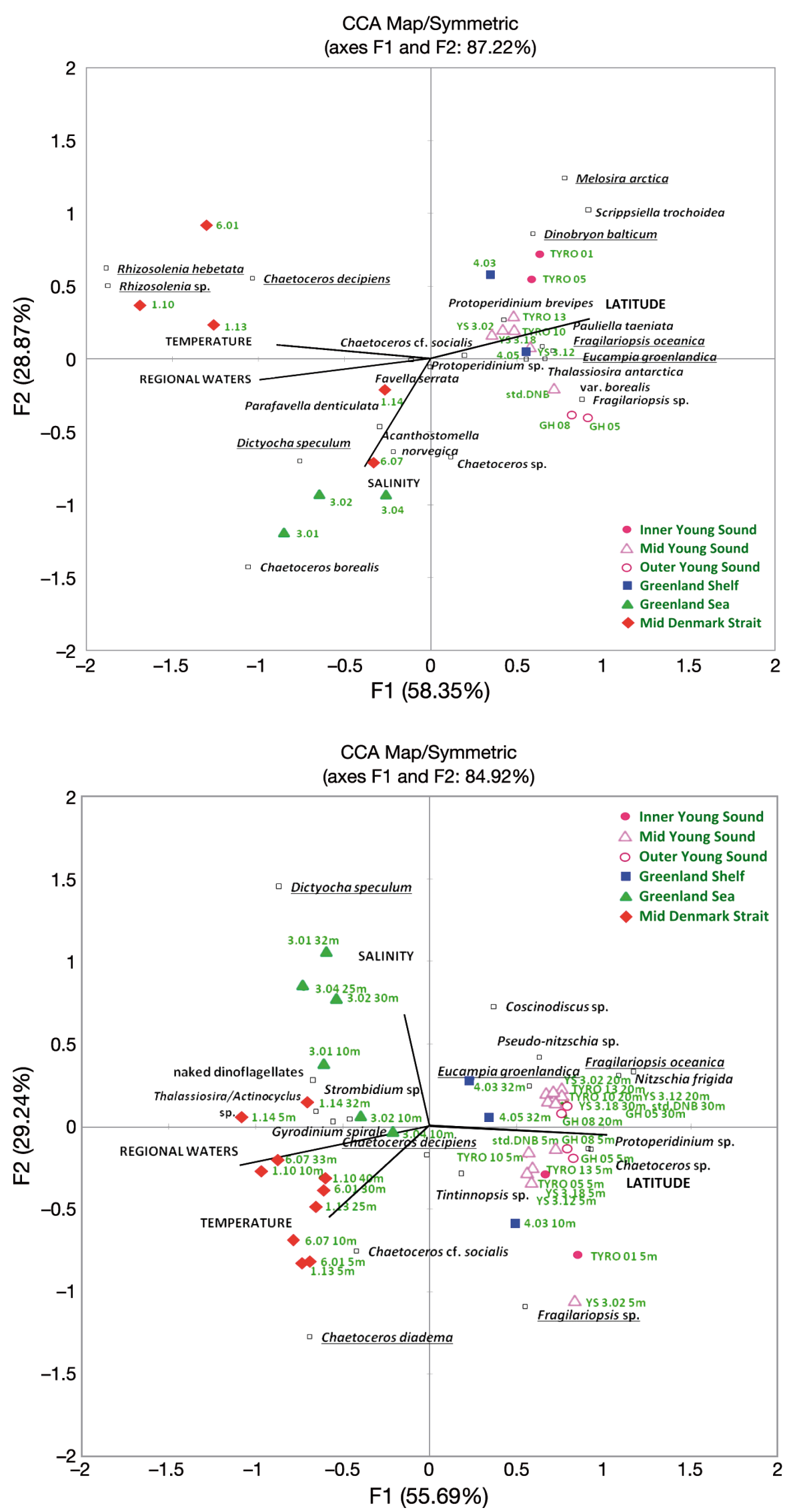

Fig. 8. Canonical correspondence analysis (CCA) biplot of samples, taxa $(>1 \%)$ and measured variables (latitude, temperature, salinity, and regional waters) along the 2 axes, based on net hauls. All measured variables (except latitude) are averaged from 0-60 m water depth. Sample stations and regions are marked; dominant taxa discussed in the text are underlined
Fig. 9. Canonical correspondence analysis (CCA) biplot of samples, taxa $(>1 \%)$ and measured variables (latitude, temperature, salinity, and regional waters) along the 2 axes, based on water bottles. All measured variables (except latitude) are from surface waters and deep chlorophyll maximum. Sample stations and regions are marked; dominant taxa discussed in the text are underlined 
Table 4. Partial canonical correspondence analysis (CCA) results investigating the importance of individual measured variables, based on spatial dataset (net hauls and water bottles) including (A) all stations and (B) selected stations where nutrients were measured, and (C) time series data (net hauls). The statistical significance of the relationship between samples and measured variables is also given. All measured variables (except latitude) for net hauls samples are averaged from 0-60 m water depths, while for water bottles are from surface waters and deep chlorophyll maximum (see the Supplement at www.int-res.com/articles/suppl/m538p099_supp.pdf)

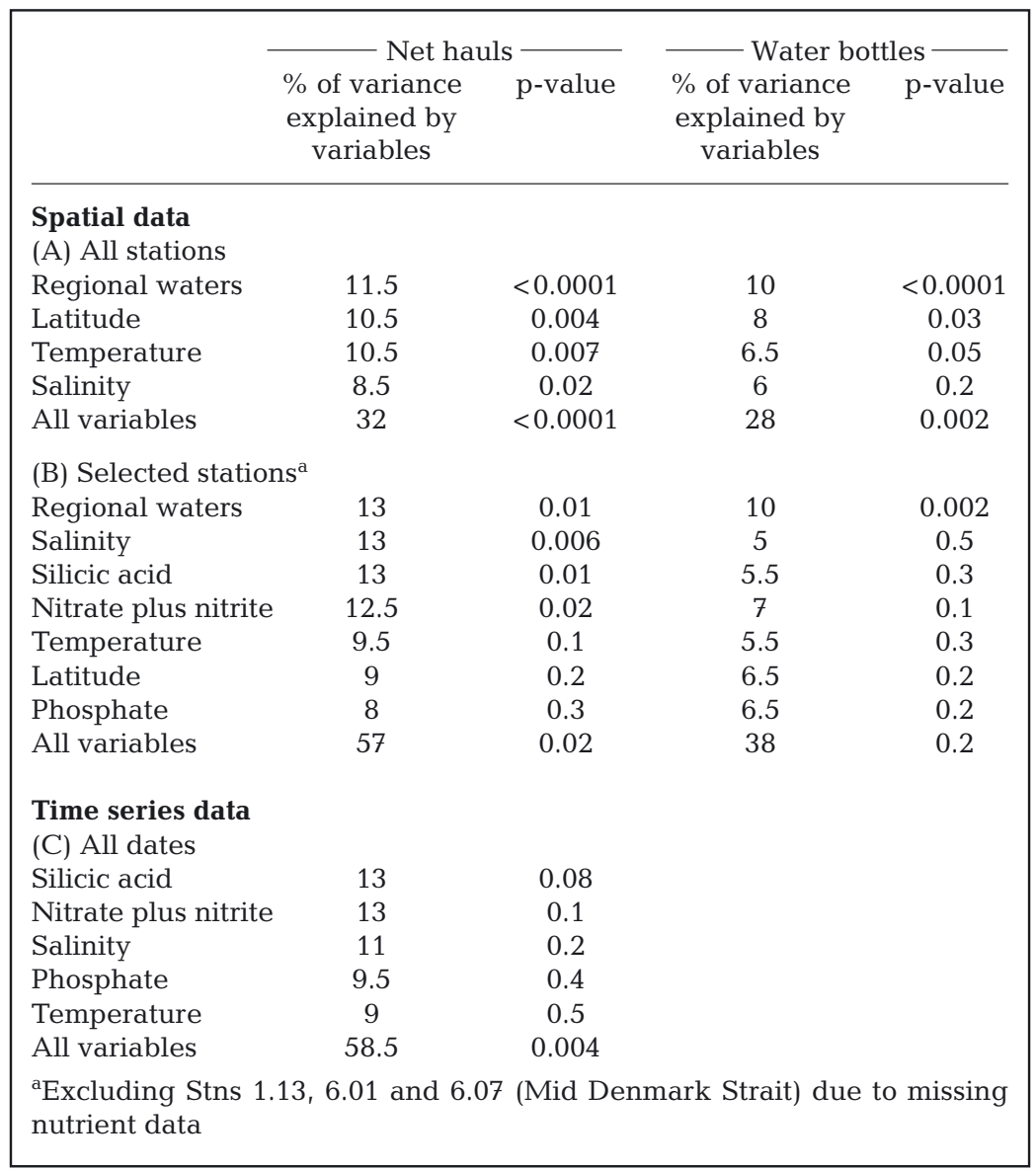

\section{Offshore waters}

The near-coast waters of the Greenland Shelf were dominated by diatoms, particularly Eucampia groenlandica. Cold waters of the Greenland Shelf originate from the EGC (Rudels et al. 2002). These waters likely favor $E$. groenlandica as this species is considered typical of northern cold water regions (Hasle \& Syvertsen 1996). Farther east, the Greenland Sea waters were characterised by diatoms (genus Chaetoceros) and silicoflagellates (DiCtyocha speculum) alongside the highest recorded salinity. The diatom genus Chaetoceros has previously been reported in association with higher salinity from the West Greenland marine waters (Krawczyk et al. 2014). D. speculum was particularly significant in sub-surface waters, where water masses were characterised as MAW. We therefore suggest a possible link between the high contribution of silicoflagellates and waters of Atlantic origin or a mixture of EGC with waters of Atlantic origin. Silicoflagellates usually make a minor contribution to 'northern' plankton assemblages (Hasle \& Heimdal 1998, Kraberg et al. 2010, RigualHernández et al. 2010), with the result that their high contribution in the studied offshore waters is unusual. The southernmost studied waters of the Mid Denmark Strait were characterised by diatoms, dinoflagellates, and

common component of the Arctic spring bloom assemblage along the Greenland coast (Quillfeldt 1996, 2001, Lovejoy et al. 2002, Jensen 2003, Krawczyk et al. 2015). The dominance of genus Fragilariopsis in mid Young Sound corresponds to melting sea ice and freshwater inputs from the inner fjord. This diatom genus also dominates the waters of outer Young Sound, where cold and more saline waters are likely influenced by the EGC transporting sea ice from the Arctic. The genus Fragilariopsis, primarily F. oceanica, has previously been described from the EGC waters around Iceland (Jiang et al. 2001). F. oceanica is also most abundant in sub-surface waters, which might indicate water mixing as a result of freshwater inputs as well as melting sea ice from water exchange between the inner and outer fjord. silicoflagellates. Diatoms together with dinoflagellates are typical components of summer plankton assemblages along coastal Northern European Seas (Kraberg et al. 2010). Warmer surface waters were recorded in the Mid Denmark Strait compared with other offshore sites, and this higher water temperature seems to have influenced diatom taxonomic composition. Diatoms were represented by the genera Chaetoceros as well as Rhizosolenia. Species belonging to genus Chaetoceros are likely to achieve high concentrations later in the blooming season and have been reported in late summer around Greenland (Grøntved \& Seidenfaden 1938, Quillfeldt 2001, Krawczyk et al. 2014), corresponding to the present sampling period (i.e. late summer 2012). Interestingly, the genus Rhizosolenia has been described 
along the convergence zone between warm and cold waters in the equatorial Pacific and was also reported in association with the sub-Arctic front west of Iceland region (Andersen et al. 2004). Knudsen \& Ostenfeld (1898) also described genus Rhizosolenia from the sub-Arctic North Atlantic as 'oceanic summer plankton' and 'Irminger Current plankton'. Thus, there may be a relationship between genus Rhizosolenia and the Icelandic Irminger Current (IIC) and/or the convergence zone of the EGC and IIC between East Greenland and Iceland.

\section{Internal comparisons}

Mid Young Sound waters revealed a striking dominance of diatoms, but colonial chrysophytes were also observed between 2009 and 2012 (Fig. 7). Diatoms were represented by alternating dominance of the genera Chaetoceros (2009 and 2011) and Fragilariopsis (2010 and 2012), which were found mainly in offshore oceanic waters and in the mid-outer fjord waters, respectively. The occurrence of the genus Fragilariopsis is probably influenced by freshwater inputs and melting sea ice from inner fjord and outer waters of the EGC, as suggested above. D. balticum was significant in Young Sound waters in the summer of 2009 but was observed irregularly in other years. This planktonic protist group, typically associated with low-salinity summer waters (e.g. Hasle \& Heimdal 1998), characterised inner Young Sound waters in this study. Such inter-annual variation in the occurrence of chrysophytes and dominant diatom genera results from a dynamic water mass exchange between the inner and outer fjord triggered by a strong temperature-salinity gradient. hypothesised, the strong temperature and salinity gradient in Young Sound driven by melting sea ice and freshwater runoff from land resulted in high variation among taxa. High variation among taxa occurs on an inter-annual basis in Young Sound as a result of dynamic summer water exchange. In contrast, the more uniform offshore waters revealed less variation among taxa, with taxa related to the larger scale influence of Polar and Atlantic waters. However, an unusually high percentage of single silicoflagellate species recorded in these offshore waters but not reported elsewhere reveals the need for more research using different sampling methods sensu Rodríguez-Ramos et al. (2014), detailed statistical analyses, and time series data from wider regions.

Acknowledgements. This study received financial support from the Danish Ministry of the Environment (project: PETAX), Danish Center for Marine Research (RV 'Dana' cruise; grant No. 2012-01) and the Danish Energy Agency and Environmental Protection Agency (project: Greenland Ecosystem System - Strategic Initiative 15). The time series data were collected by the MarineBasis-Zackenberg marine climate monitoring programme, part of the Greenland Ecosystem Monitoring programme (www.g-e-m.dk), funded by the Danish Energy Agency as part of its Arctic climate support programme. We thank the Polish Narodowe Centrum Nauki (NCN) in Krakow for financial support for the Greenland studies (Grant No. 2011/03/N/ST10/05794). We thank Colin Stedmon for helping with CTD and nutrient data. We also acknowledge technical assistance provided by the crew of the 2012 R/V 'Dana' cruise along the East Greenland coast in the framework of the PETAX project. The VELUX foundation supported H.H.J. in procuring optical equipment (VKR 022608). We also thank Egon Frandsen, Thomas Krogh, Mette D. Agersted, and Ivali Lennert for participating in fieldwork and Karl Zinglersen for help with data analysis. We thank the Translation Centre at University of Copenhagen for language improvement.

\section{CONCLUSIONS}

The present study, conducted along the East Greenland coast, stresses the need to analyse the various aspects of summer planktonic protist assemblages $(>20 \mu \mathrm{m})$, from species richness to spatial and temporal variations between taxa. The 2 sampling methods applied in this study provide significant information on fjord-offshore variation and relationships with the physical environment, yet net haul samples gave a more complete picture of the planktonic richness in the photic zone than the water bottle samples. We determined that the distribution of planktonic protists is influenced mainly by regional water masses, geographic latitude, and water temperature. As

\section{LITERATURE CITED}

Aagaard K, Carmack E (1989) The role of sea ice and other fresh water in the Arctic circulation. J Geophys Res 94(C10):14485-14498

Andersen C, Koç N, Moros M (2004) A highly unstable Holocene climate in the subpolar North Atlantic: evidence from diatoms. Quat Sci Rev 23:2155-2166

Bendtsen J, Mortensen J, Rysgaard S (2014) Seasonal surface layer dynamics and sensitivity to runoff in a high Arctic fjord (Young Sound/Tyrolerfjord, $74^{\circ} \mathrm{N}$ ). J Geophys Res 119:6461-6478

Borcard D, Legendre P, Drapeau P (1992) Partialling out the spatial component of ecological variation. Ecology 73: 1045-1055

Braman RS, Hendrix SA (1989) Nanogram nitrite and nitrate determination in environmental and biological materials by vanadium(III) reduction with chemiluminescense detection. Anal Chem 61:2715-2718 
Clarke KR, Gorley RN (2006) PRIMER v6: user manual/tutorial. PRIMER-E, Plymouth

> Comiso JC, Parkinson CL, Gersten R, Stock L (2008) Accelerated decline in the Arctic sea ice cover. Geophys Res Lett 35:L01703, doi:10.1029/2007GL031972

Degerlund M, Eilertsen HC (2010) Main species characteristics of phytoplankton spring blooms in NE Atlantic and Arctic waters $\left(68-80^{\circ} \mathrm{N}\right)$. Estuaries Coasts 33:242-269

> Dodd PA, Rabe B, Hansen E, Falck E and others (2012) The freshwater composition of the Fram Strait outflow derived from a decade of tracer measurements. J Geophys Res 117:C11005, doi:10.1029/2012JC008011

- Fenchel T (1988) Marine plankton food chains. Annu Rev Ecol Syst 19:19-38

> Gradinger RR, Baumann MEM (1991) Distribution of phytoplankton communities in relation to the large-scale hydrographical regime in the Fram Strait. Mar Biol 111: 311-321

Grasshoff K, Erhardt M, Kremling K (1983) Methods of seawater analysis. Verlag Chemie, Weinheim

> Graversen RG, Mauritsen T, Tjernström M, Källén E, Svensson G (2008) Vertical structure of recent Arctic warming. Nature 541:53-56

Grøntved B, Seidenfaden G (1938) The Godthaab Expedition 1928: the phytoplankton of the waters west of Greenland. Medd Gronl 82:5-380

> Hamilton JM, Collins K, Prinsenberg SJ (2013) Links between ocean properties, ice cover, and plankton dynamics on interannual time scales in the Canadian Artic Archipelago. J Geophys Res 118:5625-5639

- Hanna E, Huybrechts P, Steffen K, Cappelen J and others (2008) Increased runoff from melt from the Greenland Ice Sheet: a response to global warming. J Clim 21: 331-341

Hansen HP, Koroleff F (1999) Determination of nutrients. In: Grasshoff K, Kremling K, Ehrhardt M (eds) Methods of seawater analysis, 3rd edn. Wiley-VCH, Weinheim, p 159-228

Hasle GR, Heimdal BR (1998) The net phytoplankton from Kongsfjorden, Svalbard, July 1988, with general remarks on species composition of arctic phytoplankton. Polar Res $17: 31-52$

Hasle GR, Syvertsen EE (1996) Marine diatoms. In: Tomas CR (ed) Identifying marine diatoms and dinoflagellates. Academic Press, San Diego, CA, p 5-385

Horner R (2002) A taxonomic guide to some common marine phytoplankton. Biopress, Bristol

Jensen KG (2003) Holocene hydrographic changes in Greenland coastal waters. PhD dissertation, University of Copenhagen

> Jiang H, Siedenkrantz MS, Knudsen KL, Eiríksson J (2001) Diatom surface sediment assemblages around Iceland and their relationship to oceanic environmental variables. Mar Micropaleontol 41:73-96

Juul-Pedersen T, Rysgaard S, Batty P, Mortensen J and others (2010) Nuuk basic: the MarineBasis programme. In: Jensen LM, Rasch M (eds) Nuuk ecological research operations, $4^{\text {th }}$ annual report. National Environmental Research Institute, Aarhus University, Aarhus, p 45-66

Juul-Pedersen T, Arendt KE, Mortensen J, Rysgaard S and others (2012) Nuuk basic: the MarineBasis programme. In: Jensen LM, Rasch M (eds) Nuuk ecological research operations, $6^{\text {th }}$ annual report. National Environmental Research Institute, Aarhus University, Aarhus, p 47-67

Keck A, Wiktor J, Hapter R, Nilsen R (1999) Phytoplankton assemblages related to physical gradients in an Arctic glacier-fed fjord in summer. ICES J Mar Sci 56(Suppl): 203-214

Knudsen M, Ostenfeld C (1898) Overfladevandets temperature, saltholdighed og plankton paaislandske og grønlandske Skibsrouter. Bianco Lunos Kgl. Hof-Bogtrykkeri, Copenhagen

Kraberg A, Baumann M, Dürselen CD (2010) Coastal phytoplankton: photo guide for northern European seas. Verlag Dr. Friedrich Pfeil, München

Krawczyk DW, Witkowski A, Waniek JJ, Wroniecki M, Harff J (2014) Description of diatoms from the Southwest to West Greenland coastal and open marine waters. Polar Biol 37:1589-1606

Krawczyk DW, Witkowski A, Juul-Pedersen T, Arendt KE, Mortensen J, Rysgaard S (2015) Microplankton succession in a SW Greenland tidewater glacial fjord influenced by coastal inflows and run-off from the Greenland Ice Sheet. Polar Biol 38:1515-1533

> Langehaug HR, Falck E (2012) Changes in the properties and distribution of the intermediate and deep waters in the Fram Strait. Prog Oceanogr 96:57-76

Leong H, Bellerby K, Carmack E, Denisenko S and others (2005) Marine systems. In: Symon C, Arris L, Heal B (eds) Arctic climate impact assessment (ACIA). Cambridge University Press, Cambridge, p 453-538

Lovejoy C, Legendre L, Martineau MJ, Bâcle J, Quillfeldt $\mathrm{CH}$ (2002) Distribution of phytoplankton and other protists in the North Water. Deep-Sea Res II 49:5027-5047

Mees J, Boxshall GA, Costello MJ, Hernandez F and others (2015) WoRMS: world register of marine species. www. marinespecies.org (accessed 21 Jul 2015)

Okolodkov YB, Hapter R, Semovski SV (2000) Phytoplankton in Kongsfjorden, Spitsbergen, July 1996. Sarsia 85: 345-352

Quillfeldt CH (1996) Ice algae and phytoplankton in north Norwegian and Arctic waters: species composition, succession and distribution. PhD dissertation, University of Tromsø

Quillfeldt CH (1997) Distribution of diatoms in the Northeast Water Polynya, Greenland. J Mar Syst 10:211-240

Quillfeldt CH (2001) Identification of some easily confused common diatoms species in Arctic spring blooms. Bot Mar 44:375-389

Quillfeldt CH (2005) Common diatom species in Arctic spring blooms: their distribution and abundance. Bot Mar 43:499-519

Rigual-Hernández AS, Bárcena MA, Sierro FJ, Flores JA and others (2010) Seasonal to interannual variability and geographic distribution of the silicoflagellate fluxes in the Western Mediterranean. Mar Micropaleontol 77 : $46-57$

> Rodríguez-Ramos T, Dornelas M, Marañón E, Cermeño P (2014) Conventional sampling methods severely underestimate phytoplankton species richness. J Plankton Res 36:334-343

Rudels B, Fahrbach E, Meincke J, Budéus G, Eriksson P (2002) The East Greenland Current and its contribution to Denmark Strait overflow. ICES J Mar Sci 59: 1133-1154

Rysgaard S, Glud RN (2007) Carbon cycling in Arctic marine ecosystems: case study Young Sound. Medd Gronl Biosci 58:1-216

> Rysgaard S, Nielsen TG, Hansen B (1999) Seasonal variation in nutrients, pelagic primary production and grazing in a 
high-Arctic coastal marine ecosystem, Young Sound, Northeast Greenland. Mar Ecol Prog Ser 179:13-25

Rysgaard S, Vang T, Stjernholm M, Rasmussen B, Windelin A, Kiilsholm S (2003) Physical conditions, carbon transport and climate change impacts in a NE Greenland fjord. Arct Antarct Alp Res 35:301-312

Sejr MK, Juul-Pedersen T, Frandsen E, Blicher M, Lennart I (2012) Zackenberg basic: the MarineBasis programme. In: Jensen LM (ed) Zackenberg ecological research operations, $17^{\text {th }}$ annual report. National Environmental Research Institute, Aarhus University, Aarhus, p 65-76

Sheldon RW, Parsons TR (1967) A continuous size spectrum for particulate matter in sea. J Fish Res Board Can 24: 909-916

Siegel DA, Franz BA (2010) Century of phytoplankton change. Nature 466:569-571

Sosik HM, Chisholm SW, Olson RJ (1989) Chlorophyll fluo-

Editorial responsibility: Robert Condon, Wilmington, North Carolina, USA rescence from single cells: interpretation of flow cytometric signals. Limnol Oceanogr 34:1749-1761

Strom SL, Olson MB, Macri EL, Mordy CW (2006) Crossshelf gradients in phytoplankton community structure, nutrient utilization, and growth rate in the coastal Gulf of Alaska. Mar Ecol Prog Ser 328:75-92

Sutherland DA, Pickart RS (2008) The East Greenland Coastal Current: structure, variability, and forcing. Prog Oceanogr 78:58-77

Throndsen J, Hasle GR, Tangen K (2007) Phytoplankton of Norwegian coastal waters. Almater Forlag As, Oslo

Utermöhl H (1958) Zur Vervollkommnung der quantitative Phytoplanktonmethodik. Mitt Int Ver Theor Angew Limnol 9:1-39

Vinther BM, Buchardt SL, Clausen HB, Dahl-Jensen D and others (2009) Holocene thinning of the Greenland ice sheet. Nature 461:385-388

Submitted: November 24, 2014; Accepted: July 24, 2015

Proofs received from author(s): October 13, 2015 